\title{
Festuca carpetana (Poaceae), a new species for the Iberian flora
}

\author{
Vicenta de la Fuente (*) \& Daniel Sánchez-Mata (**)
}

\begin{abstract}
Fuente, V. de la \& Sánchez-Mata, D. Festuca carpetana (Poaceae), a new species for the Iberian flora. Lazaroa 35: 133-137 (2014).

A new species is proposed for the Iberian Peninsula flora: Festuca carpetana. A brief discussion and justification are presented, along with the main differences between Festuca indigesta Boiss. and the new proposed species, including two original plates from SEM samples .
\end{abstract}

Keywords: Poaceae, Festuca, Iberian flora.

Resumen: Fuente, V. de la \& Sánchez-Mata, D. Festuca carpetana (Poaceae), nueva especie para la flora ibérica. Lazaroa 35: 133-137 (2014).

Se propone una nueva especie para la flora ibérica: Festuca carpetana. Se presenta la oportuna justificación y discusión así como las diferencias con Festuca indigesta Boiss. incluyéndose dos láminas de fotografías obtenidas en SEM referidas a ambos taxones.

Palabras clave: Poaceae, Festuca, Flora Ibérica.

Festuca carpetana Fuente, Sánchez-Mata \& Rivas Mart., spec. nov.

Typus. "In fissuris superior reg. subalpina monts. Carpetan. supra Navacerrada (Castellanova)", legit. J. Lange, 21.06.1852 (K). This material was selected by Ortúñez and Fuente [in Willdenowia 27: 64, November 17, 1997] as lectotypus of Festuca curvifolia Lag. ex Lange (isolectotypus in P) (cf. ORTÚÑEZ \& FUENTE, 1997).

Synonyms. Festuca curvifolia Lag. ex Lange, Vidensk. Meddel. Dansk. Naturhist. Foren. Kjobenhavn 1860(1): 51.1861, nom. illeg.

Festuca indigesta subsp. lagascae Cebolla \& Rivas Ponce in Fl. Médit. 9: 141. 1999.

Festuca indigesta subsp. curvifolia (Lag. ex Lange) Rivas Mart., Fuente \& Ortúñez in Itinera Geobot. 15: 701.2002, nom. illeg.
Description. sub Festuca indigesta subsp. lagascae Cebolla \& Rivas Ponce in Fl. Médit. 9: 141. 1999; locus: España, Madrid, Rascafría, Cabezas de Hierro, 30TVL21, 2383 m, 27 Jun 1997, legit. Cebolla \& J. López Rodríguez (MA 680343).

Festuca carpetana is proposed here as a new specific name to substitute the illegitimate name Festuca curvifolia Lag. ex Lange, from Guadarrama Range Mountains, because Lange mentioned as synonym Festuca duriuscula var. hystrix (Boisss.) Boiss. (Festuca hystrix Boiss., a SpanishMoroccan diploid taxon from calcicolous and ultramafic areas) and illegitimate the Lagasca's name.

We assume that Lange's proposal, attributed to Lagasca, did not reflect the original ideas on this taxon. We do not know the whereabouts of Lagasca's pristine materials cited by Lange (('in herb. hort. matrit.') which would correspond to

\footnotetext{
* Departamento de Biología. Facultad de Ciencias. Universidad Autónoma de Madrid. Cantoblanco. E-28049 Madrid, Spain. E-mail: vicenta.fuente@uam.es

** Departamento de Biología Vegetal II. Facultad de Farmacia. Universidad Complutense. E-28040 Madrid, Spain. E-mail: dsmata@farm.ucm.es
} 
those selected originally by ORTÚÑEZ \& FUENTE (November 17, 1997), who chose a lectotype for the name Festuca curvifolia Lag. ex Lange within the Carpetan materials for the Lagasca taxon located and identified at the Kew Botanical Garden Herbarium (K) and the Natural History Museum Herbarium in Paris $(\mathrm{P})$, as mentioned in Lange's protologue. Moreover, Lange includes the Boissier taxon Festuca duriuscula var. hystrix (Boiss.) Boiss. -1844- (Festuca hystrix Boiss., 1838) as a synonym in the protologue of Festuca curvifolia Lag. ex Lange, supporting this inclusion by the mention of his own herbarium materials. CEBOLLA \& al. (December, 1997) -after ORTÚÑEZ \& FuENTE (op. cit.)- selected a superfluous lectotype with the name Festuca curvifolia within the materials from Burgos which correspond sensu stricto to Boissier's taxon.

Recently, Devesa \& al. (2013) proposed Festuca curvifolia Lag. ex Lange as nomen superfluum et illegitimum, identifying this name with Festuca hystrix Boiss. These authors recognise the priority of the lectotype selected by FUENTE \& al. (1997) over CeBolla \& al. (1997), and the location of the correct lectotype within Carpetan materials in high-mountain areas.

Festuca carpetana is an important element of the psycroxerophilous hemicryptophyte grasslands developed on siliceous substrates throughout supramediterranean, submediterranean supratemperate and submediterranean orotemperate mountain areas in central and central-northeastern territories of the Iberian Peninsula (Guadarrama, Ayllón, Neila, Urbión and Demanda ranges), and framed within the alliances Minuartio-Festucion carpetanae (curvifoliae) [Minuartio-Festucion carpetanae Rivas-Martínez 1964 corr. hoc loco; bas.: Minuartio-Festucion indigestae Rivas-Martínez 1964 in An. Inst. Bot. Cavanilles 21(1): 147, art. 43 ICPN -WeBER \& al., 2000-] and Hieracio castellani-Plantaginion radicatae Rivas-Martínez \& Cantó 1987 (Festucetalia indigestae, Festucetea indigestae) (cf. RIVAs-MARTíNEZ \& al., 2001-). The distribution of this species was published by FuENTE, OrTúÑEZ \& FERRERO (1997) and FUENTE \& ORTÚÑEZ (1998).

The specific rank proposed for Festuca carpetana is based on the morphological characters published by ORTúÑEZ \& FUENTE (1997) and
FUENTE \& ORTÚÑEZ (1998), and also on the karyological characters according to FUENTE, ORTúÑEZ \& FERRERO (1997, 1999); all these traits allow Festuca carpetana to be easily distinguished from Festuca indigesta Boiss.

Festuca carpetana presents culms of 10-27 cm, leaf sheaths of 1.5-4 cm closed for half its length. Ligules $0.20-0.25 \mathrm{~cm}$ long; unequal and obtuse auricles, ciliate. Blades 3-12 cm long, curved, glabrous; apex of the leaves acute, slightly pungent and aculeate. Leaf blade cross section obovate, $0.65-1.1$ $\mathrm{mm}$ in diameter, with 7 veins; sclerenchyma forming a complete ring with a thickness of 3-4 cells, 2-4 grooves, 1-3 ridges (Figures 1a, 1b, 1c). Panicle short, with 1-3 dense lanceolate branches with 8-20 spikelets. Spikelets with unequal acute glumes; lower glume 1.8-3.3 mm long; upper glume 2.5-4.4 x 0.9-1.4 mm. Lemma 3.3-5.5 x 1.3-1.7 mm; awns 1-2 mm long. PALEA 3.1-4.75 x 0.5-0.85 mm, oblong and bidentate $2 \mathrm{n}=42$. Icon.: FuENTE \& ORTÚÑEZ (1998: 88 sub Festuca cuvifolia).

Festuca indigesta Boiss. presents culms of 14$53 \mathrm{~cm}$, leaf sheaths closed for 2/3-3/4 its length, with 7-9 veins. Ligules 0.2-0.4 mm long; obtuse auricles, ciliate. Blades 7-18 cm long, rigid, erectcurved, glaucous with the apex acuminate, acute and very pungent, not aculeate. Leaf blade cross section elliptic, $0.85-1.35 \mathrm{~mm}$ in diameter, with up to 9 veins; sclerenchyma forming a complete ring with a thickness of 3-5 cells, 4-5 grooves, 35 ridges (Figures 2a, 2b, 2c). Panicle with 3-4 dense ovate-lanceolate branches, with 14-29 spikelets. Spikelets with unequal and acuminate glumes; lower glume 2-2.7 mm long; upper glume 3.3-4.3 x 1.3-1.6 mm, acuminate. Lemma 3.8-4.8 x 1.3-1.7 mm; awns 1-1.6 mm long. Palea 3.6-4.4 $\mathrm{x}$ 0.7-0.9 mm, oblong and bidentate $2 \mathrm{n}=42$. Icon.: FUENTE \& ORTÚÑEZ (1998: 84).

Micromorphological data were obtained following the protocols proposed by ORTÚÑEZ \& Fuente (2010) and Rufo Franco \& Fuente (2013) using scanning electronic microscopy techniques (SEM) in a Philips XL30 Hitachi S3000N (Figures 1, 2).

The epidermic cells of the leaves are covered by a dense layer of epicuticular wax, threadlike in Festuca carpetana and forming shaped plates in Festuca indigesta Boiss. (Figures 1, 2). In the 


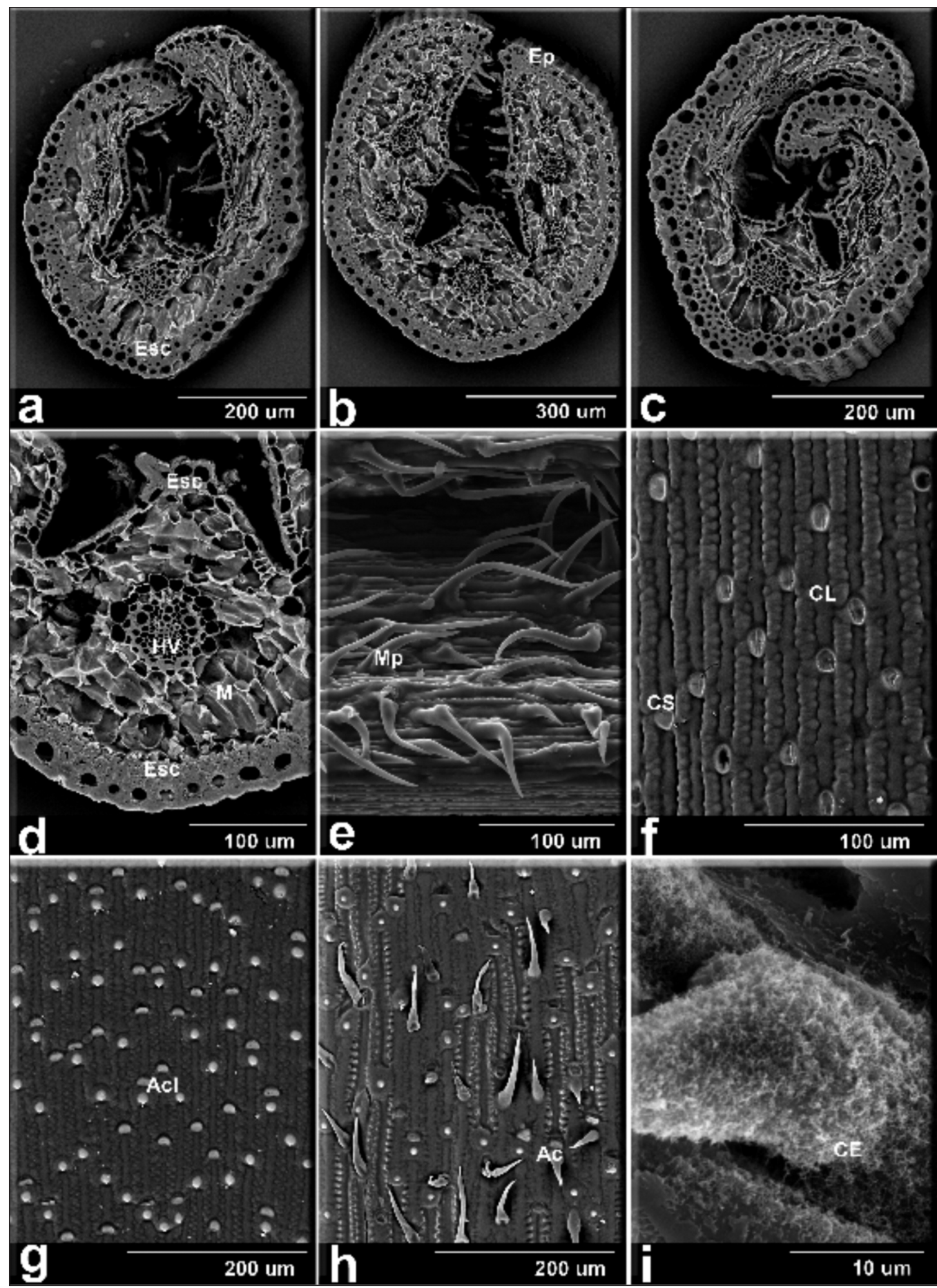

Figure 1. - Festuca carpetana (Segovia, Sierra de Ayllón, Pico del Lobo, 2100 m asl, 28-6-2012): a, b, c, blade cross section; d, detail of the central vessel and sclerenchyma cells; e, adaxial leaf epidermis; $f$, detail of the abaxial leaf epidermis with silica bodies; $g$, lemma abaxial surface; $h$, palea abaxial surface; $i$, waxes from the adaxial leaf surface. Ac, large prickle; Acl, small prickle; Ep, epidermis; Esc, sclerenchyma cells; Hv, vascular bundle; Ce, epicutelar waxes; Cs, silica cell; $\mathrm{Cl}$, long cell; $\mathrm{M}$, mesophyll; $\mathrm{Mp}$, large hair. 

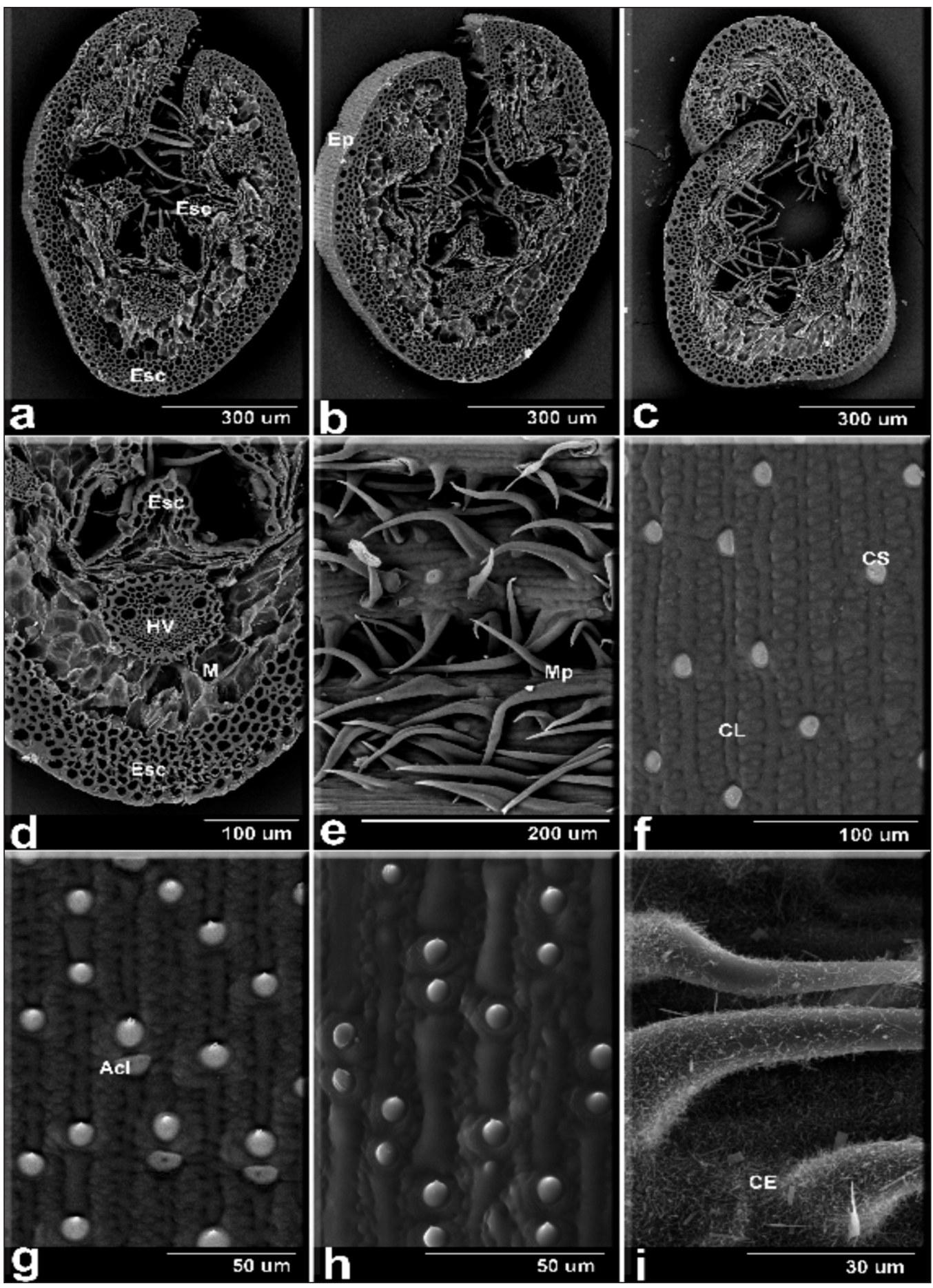

Figure 2. - Festuca indigesta (Granada, Sierra Nevada, Peñones de San Francisco, 2570 m asl, 14-8-1992): a, b, c, blade cross section; d, detail of the central vessel and sclerenchyma cells; e, adaxial leaf epidermis; $f$, detail of the abaxial leaf epidermis with silica bodies; g, lemma abaxial surface; h, palea abaxial surface; i, waxes from the adaxial leaf surface; Ac, large prickle; Acl, small prickle; Ep, epidermis; Esc, sclerenchyma cells; Hv, vascular bundle; Ce, epicutelar waxes; $\mathrm{Cs}$, silica cell; $\mathrm{Cl}$, long cell; $\mathrm{M}$, mesophyll; $\mathrm{Mp}$, large hair. 
abaxial epidermis there are no subsidiary cells or stomata as in other species of the subgenus Festиса. The long cells are rectangular, alternating with silica bodies (Figures 1f, 2f).

On the adaxial leaf surface there are similar stomata and subsidiary cells with parallel walls in both taxa. The rectangular long cells are joined by short cells, and both are present over the entire surface of the leaves; both taxa also present a coverage of abundant hairs up to 100 microns long (Figures 1e, 2e).

The SEM images of the epicutelar waxes covering the plants' exposed surfaces highlight the differences between the two taxa (Figures 1,2). We include a detail of the surfaces of the lemma and palea; both show plain and waved cell walls covered by prickles, hairs, and silica bodies (Figures $1 \mathrm{~g}, \mathrm{~h}, 2 \mathrm{~g}, \mathrm{~h})$.

Festuca carpetana is a hexaploid species, as revealed by the karyological studies of different populations (ORTúÑEZ \& Fuente, 1995; FERRERO,
1999; FUENTE \& al. 2001). At present, only a diploid taxon of this group is known in the Iberian Central Range mountains: Festuca vettonica Fuente, Ortúñez \& Ferrero Lom. The comparison between the karyotypes of Festuca vettonica and Festuca carpetana shows some similarities that suggest a kinship relationship. This idea supports the hypothesis of individualised origin; that is, an independent origin of the hexaploids 'continuous sclerenchyma' from a diploid ancestor in the different mountain ranges. The existence of ancestral and relict diploids in the territories where the hexaploid taxa are now dominant points to an independent and isolated origin of the hexaploids in the different mountain areas.

\section{ACKNOWLEDGEMENTS}

Our gratitude to Pru Brooke-Turner for the revision of the English version of the original manuscript of this contribution.

\section{REFERENCES}

Cebolla, C., López Rodríguez, J.A. \& Rivas Ponce, M.A. - 1997- Cinco tipificaciones en Festuca L. - Fontqueria 48: 81-89.

Cebolla, C. \& Rivas Ponce, M.A. - 1999- Festuca indigesta Boiss. subsp. lagascae Cebolla \& Rivas Ponce subsp. nova et ses relations avec le complexe Festuca indigesta Boiss. Critères utilisés lors de son étude taxonomique - Fl. Medit. 9: 131-146.

Devesa, J.A., Catalán, P., J. Müller, Cebolla, C. \& Ortúñez, E. - 2013- Checklist de Festuca L. (Poaceae) en la Península Ibérica - Lagascalia 33: 183-274.

Ferrero Lomas, L.M. -1999- Citogenética, evolución y biogeografía de las secciones Festuca L. (Intravaginales) y Eskia Willk. del género Festuca L. (Poaceae) en la Península Ibérica. Mem. Doc. (inéd.). Univ. Autónoma, Madrid.

Fuente, V., Ferrero,L.M. \& Ortúñez, E. - 2001 - Chromosome counts in the genus Festuca L. section Festuca (Poaceae) in the Iberian Peninsula - Bot. J. Linn. Soc. 137: 385-398.

Fuente, V. \& Ortúñez, E. -1998- Biosistemática de la sección Festuca del género Festuca L. (Poaceae) en la Península Ibérica - Publ. Univ. Autónoma, Madrid.

Fuente, V, Ortúñez, E. \& Ferrero, L.M. - 1997 - Contribución al conocimiento del género Festuca L. (Poaceae) en el País Vasco y Sistema Ibérico septentrional (Península Ibérica) - Itinera Geobot. 10: 317-351.
Fuente, V., Ortúñez, E. \& Ferrero, L.M. -1999- A new species of Festuca L. (Poaceeae) from the Iberian Peninsula - Parlatorea 3: 65-77.

Ortúñez, E. \& Fuente, E. - 1995 - Reports 394-400 - In: Kamari, G.,Felber, F. \& Garvari, F. (Eds.). Mediterranean chromosome number reports, 5 - Fl. Medit. 5: 261-373.

Ortúñez, E. \& Fuente. V. - 1997- On three species of Festuca L. (Poaceae) from the Central Mountain System (Spain) - Willdenowia 27: 57-67.

Ortúñez E. \& V. Fuente - 2010 - Epidermal micromorphology of the genus Festuca L. (Poaceae) in the Iberian Peninsula - Plant Syst. Evol. 284: 201-218.

Rivas-Martínez, S. - 1964- Estudio de la vegetación y flora de las sierras de Guadarrama y Gredos - An. Inst. Bot. Cavanilles 21(1): 1-325.

Rivas-Martínez, S., Fernández-González, F., Loidi, J., Lousã, M. \& Penas, A. -2001 - Syntaxonomical Checklist of Vascular Plant Communities of Spain and Portugal to association level - Itinera Geobot. 14: 1-341.

Rufo, L., Franco, A. \& Fuente, V. - 2013 - Silicon in Imperata cylindrica (L.) P. Beauv: content, distribution, and ultrastructure - Protoplasma 251 (4): 921-930.

Weber, H.E., Moravec, J. \& Theurillat, J.-P. -2000 - International Code of Phytosociological Nomenclature, 3rd ed. - J. Veg. Sci 11: 739-768. 